\title{
Consumer Awareness and Consumer Protection in Hungary
}

\author{
Robert Sandor Szucs \\ College associate professor, Ph.D, John von Neumann University, \\ Commerce, Marketing and International Business Department, Hungary
}

Doi: 10.19044/esj.2018.v14n4p61 URL:http://dx.doi.org/10.19044/esj.2018.v14n4p61

\begin{abstract}
The consumer asserts that his decisions are consistent and rational. $\mathrm{He}$ likes to believe this about himself. Based on previous surveys it can be stated that our confidence persists until the assessment of the actual level of our knowledge on consumer protection takes place, e.g. in the form of a test containing 13 substantial questions to measure the actual level of knowledge. This test was filled out by 2182 persons over 18 years of age. In overall, we can say that no matter how much we love to think about ourselves as being conscious customers, this statement is generally not true. The level of consumer protection knowledge is generally insufficient in Hungary. Only $13 \%$ of consumers have the right to say that they are knowledgeable of consumer protection at average level, while the good level was achieved only by $2.1 \%$ of the respondents.
\end{abstract}

Keywords: Marketing, consumer protection, consumer awareness, conscious customer

\section{Introduction}

Marketing and consumer protection are concepts that nowadays could be interpreted only if considered concurrently. Where one discipline ends, the other begins. They can be compared to two cogwheels nicely fitting into each other. No marketing professional can operate without knowledge of consumer protection and the same is true vice versa. In terms of marketing it is no longer the question of whether we are able to reach and influence the consumer. We can say today that we can do this effectively and efficiently. Rather, the question is whether our activity violates any legal boundaries or ethical guidelines. The two disciplines are very close to each other. In 1962, President Kennedy created the Consumer Bill of Rights (GYARMATI, 2005). According to this Bill, the consumer has the right to be informed, the right to safety, the right to choose and the right to be heard. This Bill showed that 
consumers are one of the most vulnerable groups. Undoubtedly, sellers have better information about the product or service to be sold. The benefits of the asymmetrical information supply are obviously enjoyed by the seller, while the disadvantages are clearly and unilaterally experienced by the consumer. Disadvantages and lack of expertise makes the consumer vulnerable. Shortterm thinking can be the rapid utilisation of the benefits of asymmetrical information supply from a corporate perspective. This cannot be a good strategy in the long term, or perhaps in the short term as well (active consumer protection). A well-informed consumer knowledgeable of his rights has become a fundamental corporate interest. A quick and illustrative example in support of this thought is how the electronic word-of-mouth (eWOM) advertising has become common (HENNIG-THURAU ET AL., 2004). The ignorant consumer, within a few moments, using a few words or sentences, gives a 1 star rating to a company on the relevant internet portals, with the result that this company loses potential customers and its products may become unsaleable. All these thoughts and concepts are reflected in the more advanced marketing tools including the 4E's concept. Consumer education has become one of the basic tools, not by accident. Today it has become indispensable. An inaccurate description of the product, a product missing from the stock, an unknown mark on the packaging of the product (leading to a defect in handling the product), lack of knowledge about the withdrawal options associated with an online order, imprecise information on the guarantee can lead to dissatisfied consumers. Consumers are far from being rational when making their decisions. The assumption of rationalism on the consumer side is taken into account only by the science of economics.

Conscious shopping is a desirable behaviour, but it is hindered by a number of factors that make its implementation difficult. It is commonly acknowledged fact that about $80 \%$ of purchases are emotion-based and only the remaining $20 \%$ can be deemed rational decisions. The rate of impulse purchases is not negligible either. HOYER et al. (2013) estimates the proportion of impulse purchases from 27 to $62 \%$, which is product-dependent. According to SUMIT (2013), for apparel products this proportion is approximately $40 \%$, while $14 \%$ of total impulse purchases are food products. The list could be continued indefinitely. If the consumer were really conscious, then despite all the marketing activities, it would be impossible that impulse purchases and emotional purchases achieve such a significant extent.

Nevertheless, the consumer asserts that his decisions are consistent and rational. He likes to believe this about himself. My previous research findings support this statement (SZÜCS, 2011). Consumers, on a 5-degree scale, have explicitly agreed with the statement that they are conscious customers, they do not buy unnecessary things encouraged by some advertisements and they are well aware of their consumer rights. Typically, based on these considerations 
they graded themselves 4 on a 5-grade scale. This awareness, in their view, is not true of the other consumers, they are, of course, buying unnecessary things and poorly know their rights. The consumer thinks about himself that he is a conscious customer, but this is not the case for other consumers, generally. The science of psychology knows this phenomenon as a "self-defence mechanism". If we would start out just from those answers of consumers, then we could say that the consumer is conscious and rational. If we would accept this assumption, we would make a serious mistake: we would measure not the consumer's rationality and actual knowledge, but only the consumer's attitude towards himself, which is extremely positive. In order to talk about the rationality of consumers at all, it is necessary to measure the actual level of knowledge of consumer rights. Basically we must distinguish between real and presumed awareness. Real awareness is rooted in the knowledge of consumer rights, while the presumed awareness exists only in the consumer belief in himself. Of course, the level of knowledge of consumer rights does not yet fully explain the consumer's awareness. Using a mathematical expression, I consider it as a "necessary and sufficient" condition and as a kind of foundation.

HOFMEISTER and TÖRÖCSIK (1996) used the following formulation: "The shopper is vulnerable to sellers acting on the market (...) The consumer, on the other hand, is not vulnerable. He is aware of his power, expects to get value for his money, is in solidarity with other fellow consumers, screens out those entrepreneurs in the market who act against his interests, either by deceiving the state or by willing to gain profits at the expense of consumers.". In this sense, the conscious customer is definitely a consumer, in no way a shopper. The ASSOCIATION OF CONSCIENTIOUS CUSTOMERS IN HUGARY (2017) states: "Under classical consumer protection, it is a conscious customer who does not let himself be conned. Who understands his consumer rights and exercises them." Under the effect of their strong self-defence mechanism, consumers, of course, consider themselves reasonably conscious consumers. SÜLE (2012), in his research covering 280 university students, analysed how the gender and participation in consumer protection education of the respondents had affected their consumer's awareness. In his research, he points out that female consumers are more likely to be characterised by hedonistic consumption and price sensitivity than male customers.

\section{Material and methodology}

Based on previous surveys it can be stated that our confidence persists until the assessment of the actual level of our knowledge on consumer protection takes place, e.g. in the form of a test containing 13 substantial questions to measure the actual level of knowledge. The questions were 
basically case studies on consumer protection issues. This test was filled out by 2182 persons over 18 years of age. $49.6 \%$ of the respondents were male and $50.4 \%$ were female. The survey was divided into two stages. In the first stage the test was filled out by 1143 persons between the ages of 18 and 25 (50.7\% male, $49.3 \%$ female) with approximately the same distribution within each age, between November 2016 and January 2017. In this stage, the average age within the sample was $21.5 \pm 2.3$ years. In the second stage, which was required because of the results of the first stage, 1039 people over the age of 25 (from 25 to $75+$ ) years filled out the test between October 2017 and December 2017. In the second stage, the average age was $44.8 \pm 12.9$ years. In the sample, the age group of 18 to 25 years was deliberately overrepresented, which I took into account by weighting cases. The two stages together cover the entire adult population. The test was identical in both stages. The test was written, respondents did not receive any external help for the solution. In the test, the respondents were offered detailed descriptions of a total of 13 consumer protection cases that can easily occur on weekdays and were to choose the right solution (closed-ended questions) from predefined response alternatives. The cases were to measure the consumer's knowledge in relation to customer complaint logs, missing advertised items, luring advertising, the rules on displaying prices (pricing errors) duration of guarantee and available remedies, provision of replacement equipment, length of cooling-off periods in case of domestic webshops, VAT and duty obligations in case of foreign webshops, putting prices in shop windows, placing products with expired 'use by' date on the market, the CE mark on products, and the exchange or withdrawal opportunities in case of popular and often mentioned Christmas gifts. The difficulty level of a test is always a controversial factor. To check the test, I made it filled out by several of my students who have graduated from the course on "Customer Satisfaction and Consumer Protection". For the students, the test solution did not cause any problems or difficulties; the results above 10 correct answers were very common. The highest result was 12 correct solutions. The verification on a larger sample is in progress.

The purpose of the research is to assess the level of consumer protection knowledge of the respondents and to draw conclusions about consumer's awareness, i.e. to measure awareness in terms of consumer protection.

\section{Results}

Despite numerous information, consumers still live with a big illusion in connection with gifts received for certain occasions (gifts on special occasions, such as Christmas) (e.g., 'I received two identical pants, I would take one of them back'). Most consumers are convinced that exchanging the 
unwanted gifts is a legitimate duty of the trader when a customer receives two of the same gift (44.9\%). If the exchange is unsuccessful, the purchase price can be refunded (40.7\%). Only $14.3 \%$ of the respondents are aware that neither the exchange nor the refund of the purchase price are obligatory for the trader. From the results obtained, it is clear that the respondents cannot distinguish between a gesture of goodwill of/additional service provided by the trader and its legal obligation, so this leads to the development of misconceptions.

Only $13.2 \%$ of the respondents were able to answer the question of whether VAT and/or duties are payable in connection with the product price of USD 52.99 (approximately HUF 15,000) ordered from a Chinese webshop, no matter that this generation feels particularly homely in the online ordering world. A common mistake is that consumers explain the lack of VAT and duty-payment obligations so that people living in EU countries do not have to pay such a burden $(12.7 \%)$ or do not have to deal with such things as private persons $(17.5 \%)$. Among the erroneous explanations given concerning the lack of the obligation to pay are the one-off orders (8.7\%) and the small amount purchases (14.5\%), which are also mentioned as a reason. VAT and also duties would be paid by $17.4 \%$ of the respondents.

The respondents are convinced that an obligatory guarantee shall be due on a HUF 4,999 technical product (hairdryer). Only $19.7 \%$ of the respondents knew this was not really the case. The erroneous assumption is also presumably the result of additional commitment undertaken by traders since often traders offer up to 2-3 years' warranty on technical products worth under HUF 10,000, which is not a legal requirement.

In connection with the case of product (sweater) ordered from a domestic webshop, only $22.5 \%$ of respondents were able to choose correctly that they shall be entitled to a 14-day right of withdrawal without stating reasons in relation to the product purchased. A common mistake is that 3,8 or even 30 days were chosen in the answer instead of the 14 days mentioned above. The possibility of a 3-day withdrawal was chosen by $27.0 \%$ of the respondents, while 8 days were chosen by $14.4 \%$ and 30 days by $9.2 \%$ of the respondents. It is clear from the responses that the respondents do not know the concept of unreasoned withdrawal, in their view, the consumer has no right to complain if the sweater is already worn and proved to be faultless (7.9\%).

The situation with regard to the provision of replacement equipment is also no better. Only $25.3 \%$ of the respondents knew the provision of replacement equipment was not obligatory by law for the trader in case of a higher price smartphone. According to many respondents (31.8\%), in case of the purchase price above HUF 50,000, not only the provision of the replacement equipment is obligatory but the replacement product should be of the same price category as the original product. $42.8 \%$ of the respondents believe that the provision of replacement equipment is obligatory for the trader 
by law, but the replacement product may be of a poorer quality than the originally purchased product.

It is striking that only $56.2 \%$ of the respondents were able to say that the mandatory legal guarantee period for a technical product (television) was 12 months. A common mistake is that the consumer is unaware of the basic concepts (according to $15.8 \%$ there is a huge difference between the warranty and the guarantee). All kind figures appeared in the responses relating to the warranty period $(6,18,36,60$ months).

The situation is not much more favourable in the case of a really trivial question, such as pricing errors. Only $59.9 \%$ of the respondents knew that the lower price on the product label should apply if they encountered such a case. $34.7 \%$ of the respondents said that the higher price for the consumer should be accepted, but the consumer could make a record in the customer complaint log about his displeasure.

The meaning of the $\mathrm{CE}$ marking on the products was wrongly interpreted by $38.3 \%$ of the respondents. The most frequent mistake in the wrong answers was stating that the CE mark means a proof of high quality $(21.1 \%)$. There is hardly a better situation with the customer complaint log. $42.7 \%$ of respondents gave a bad or inaccurate response to the case outlined. It is a common mistake that the respondents think that they need to personally ask the customer complaint log from the shop leader $(31.0 \%)$

However, in relation of one of the questions, the proportion of correct answers is high. $80.7 \%$ of the respondents knew that products (in our example, canned food) could not be sold, on the market, if even at a discounted price, after the expiration of the guaranteed quality date. I would like to note that the proportion of respondents choosing the answer that "it is lawful because the canned food is hermetically sealed food intended for long-term consumption (with virtually unlimited guaranteed quality date, similar to sugar and salt)" was $19.3 \%$.

The respondents estimated the number of their correct answers after completing the test. The respondents thought that on average they had given correct answers to 8-9 questions (averages 8.5). On the other hand, the evaluation of the test shower that the respondents had significantly overestimated the level of their consumer protection knowledge. The actual number of correct answers per one respondent was only 5.1 on average instead of 8.5 which was guessed. In projection to 13 test questions this means that the young people succeeded in passing the test for $39.2 \%$. To illustrate this, the reward for performance would be a bitter failure if we had to rate the performance using grades as in a school. The results are well illustrated by the fact that the proportion of those with sufficient performance according to the education system is $24.5 \%$, which is astonishingly low. For the total population, men averaged 5.24 correct answers for case studies, while for 
women this value was 5.04. The result is all the more interesting because in the young age (18-20 years age group) the number of correct answers is higher in the case of women (4.48 vs. 4.39). As the age progresses, men make up for this shortcoming. It is obvious that in none of the cases the difference is significant among the genders, but we have to say that men have performed, to a minor extent, better. As for age, there is also a trend in the average number of correct answers, even if that is not so clear (see Figure 1.).

Figure 1. Average number of correct answers accordig to age

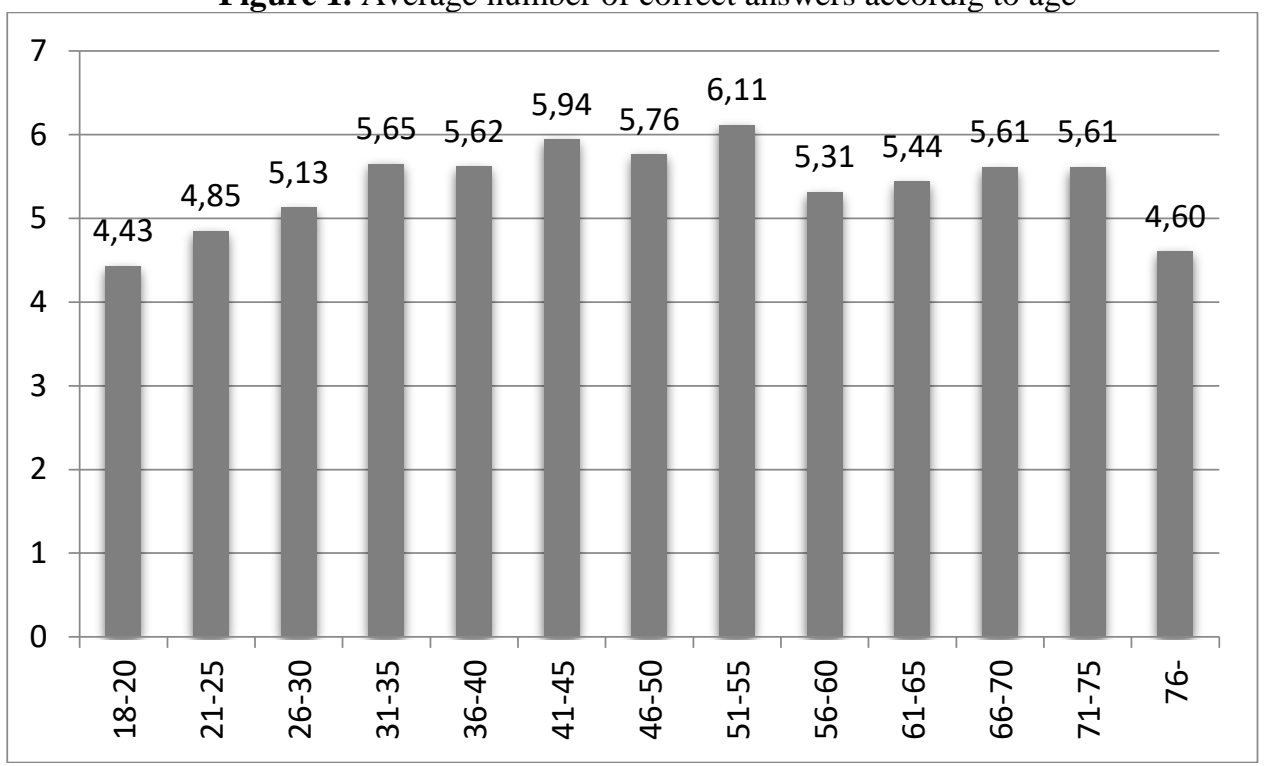

Source: own research, 2018

It can be seen that the least correct answers were given by the age group of 18-25 years and the age group of 75 or over. Based on the data, we have to say that these age groups are the most vulnerable groups and least conscious, in terms of consumer protection (18-25). The most correct answers were given by the age group 41-55 years.

The two survey stages, that is, those under the age of 25 vs. those over the age of 25, showed significant differences. The performance of the younger age group members was clearly poorer (see Table 1.).

Table1: Ratio of correct answers in case studies according to age

\begin{tabular}{|c|c|c|}
\hline Case Studies & $\begin{array}{c}\text { Ratio of correct } \\
\text { answers under the age } \\
\text { of 25 }(\%)\end{array}$ & $\begin{array}{c}\text { Ratio of correct } \\
\text { answers over the age } \\
\text { of 25 }(\%)\end{array}$ \\
\hline $\begin{array}{c}\text { Case study on the log of consumer } \\
\text { complaints }\end{array}$ & 48.6 & 66.5 \\
\hline $\begin{array}{c}\text { Case study on the unrealistically low } \\
\text { level of starting inventory }\end{array}$ & 29.3 & 38.2 \\
\hline Case study on luring advertising & 21.9 & 30.7 \\
\hline Case study on pricing errors & 56.7 & 63.4 \\
\hline
\end{tabular}




\begin{tabular}{|c|c|c|}
\hline $\begin{array}{c}\text { Case study on low cost product } \\
\text { guarantee (below HUF 10,000) }\end{array}$ & 21.1 & 18.1 \\
\hline $\begin{array}{c}\text { Case study on the obligation to provide } \\
\text { replacement equipment }\end{array}$ & 22.5 & 28.4 \\
\hline $\begin{array}{c}\text { Case study on the period of withdrawal } \\
\text { without stating reasons when shopping } \\
\text { online }\end{array}$ & 19.2 & 14.0 \\
\hline $\begin{array}{c}\text { Case study on foreign webshop VAT } \\
\text { and customs duty obligation }\end{array}$ & 12.4 & 47.6 \\
\hline $\begin{array}{c}\text { Case study on displaying prices in shop } \\
\text { windows }\end{array}$ & 39.4 & 64.4 \\
\hline $\begin{array}{c}\text { Case study on the guarantee period of } \\
\text { durable consumer goods }\end{array}$ & 48.7 & 84.0 \\
\hline $\begin{array}{c}\text { Case study on the placing of a product } \\
\text { with expired 'use by' date on the market }\end{array}$ & 77.5 & 62.3 \\
\hline Case study on CE marking & 61.0 & 17.3 \\
\hline $\begin{array}{c}\text { Case study on the possibility to return } \\
\text { Christmas gifts }\end{array}$ & 11.5 & \\
\hline
\end{tabular}

Source: own research, 2018

Measuring the relationship between the education level and the average number of correct answers is not a simple task, since the gender and age of the respondent can also have an influence based on the previous information, and there could be numerous variations. Generally speaking, assuming the same age, the average number of correct answers shows an upward trend with the increasing level of education. Taking into consideration the highest level of education, the average number of correct answers was 4.29 for those with education less than 8 years of primary school, 4.86 for graduates who completed 8 years of primary school, 5.20 for graduates who completed secondary school education, 5.83 for graduates who completed tertiary education. If we measure the performance of secondary school students versus tertiary-level students, the upward trend can be observed here as well (4.14 vs. 4.92). However, it is important to emphasize the power of the experience gained with age as it can be seen that an older person with education less than 8 years of primary school can give more correct answers than a young secondary school student, and this fact is in any way astonishing. On average, people with economic qualifications also provided more correct answers than those who did not have such a qualification ( 4.95 vs. 5.48). If we combine these factors with one another, e.g. a man with a tertiary education averaged 6.26 correct answers in the test.

Only $13.1 \%$ of the respondents were able to give at least 8 correct answers, and this would correspond to an average grade in the school system. Characterisation of average grade achievers: the proportion of men is $56.8 \%$, the proportion of those with tertiary education is $25.0 \%$, and the proportion of those with economic qualification is $40.7 \%$. The best performing age group 
was three age groups among middle aged people (41-45 years, 46-50 years, 51-55 years), their weighted proportion in the order as they are written is between 11.0 and $18.3 \%$. The good grade (10 correct answers) was achieved only by $2.1 \%$ of the respondents. Here, the proportion of men reaches $66.7 \%$, the proportion of those with tertiary education is $33.3 \%$, and the proportion of those with economic qualifications is $46.7 \%$. In terms of age, those belonging to the age groups of 41-45, 46-50 and 51-55 years performed the best. Only 1 person out of 2182 filled out the whole test correctly.

In this paper the level of awareness in terms of consumer protection is measured by 13 case studies. Of course there are some other influencing factors, e.g. gender, age, education level of the respondents and the number of right answers thought in advance. The answers were evaluated through factor analysis. Based on the results of the factor analysis the level of consumer protection knowledge is influenced by 6 factors. I would like to forbear from giving names of different factors but I publish the most important results. The 13 case studies (questions) are grouped into 4 factors. Of course these case studies are the most important factors. The influencing effect, the explained variance is $35.3 \%$. I think there is not surprising.

Factors 5 and 6 are a lot more interesting. Factor 5 contains the age of the respondent (explained variance is 5.4\%). Factor 6 includes other demographic factors, such as age, schooling (possibly economic training). The explanatory factor here is $5.3 \%$. The explained total variance is $46.1 \%$, which can be judged to be favourable. Similar to the first stage of the research, factor analysis also highlighted the importance of age and other demographic factors.

In my research I segmented the respondents using cluster analysis ( $\mathrm{K}$ means cluster) by the level of consumer protection knowledge. In the cluster analysis I involved all of case studies and other influencing factors which are influencing the level of consumer protection knowledge.

Table1: Ratio of correct answers according to clusters

\begin{tabular}{|c|c|c|c|c|c|c|}
\hline $\begin{array}{c}\text { Segment } \\
\text { Case studies }\end{array}$ & $\begin{array}{c}1^{\text {st }} \\
\text { segment }\end{array}$ & $\begin{array}{c}2^{\text {nd }} \\
\text { segment }\end{array}$ & $\begin{array}{c}3^{\text {rd }} \\
\text { segment }\end{array}$ & $\begin{array}{c}4^{\text {th }} \\
\text { segment }\end{array}$ & $\begin{array}{c}5^{\text {th }} \\
\text { segment }\end{array}$ & F-rate \\
\hline $\begin{array}{c}\text { Case study on the log of } \\
\text { consumer complaints }\end{array}$ & 0.82 & 0.78 & 0.58 & 0.48 & 0.35 & 83.884 \\
\hline $\begin{array}{c}\text { Case study on the } \\
\text { unrealistically low level of } \\
\text { starting inventory }\end{array}$ & 0.50 & 0.50 & 0.33 & 0.23 & 0.21 & 40.679 \\
\hline $\begin{array}{c}\text { Case study on luring } \\
\text { advertising }\end{array}$ & 0.45 & 0.44 & 0.20 & 0.19 & 0.12 & 58.587 \\
\hline Case study on pricing errors & 0.79 & 0.83 & 0.48 & 0.53 & 0.44 & 63.556 \\
\hline $\begin{array}{c}\text { Case study on low cost } \\
\text { product guarantee (below } \\
\text { HUF 10,000) }\end{array}$ & 0.17 & 0.25 & 0.18 & 0.16 & 0.21 & 3.314 \\
\hline $\begin{array}{c}\text { Case study on the obligation to } \\
\text { provide replacement } \\
\text { equipment }\end{array}$ & 0.29 & 0.39 & 0.24 & 0.22 & 0.16 & 18.504 \\
\hline
\end{tabular}




\begin{tabular}{|c|c|c|c|c|c|c|}
\hline $\begin{array}{l}\text { Case study on the period of } \\
\text { withdrawal without stating } \\
\text { reasons when shopping online }\end{array}$ & 0.34 & 0.41 & 0.17 & 0.16 & 0.11 & 44.757 \\
\hline $\begin{array}{c}\text { Case study on foreign } \\
\text { webshop VAT and customs } \\
\text { duty obligation }\end{array}$ & 0.16 & 0.22 & 0.11 & 0.09 & 0.10 & 10.889 \\
\hline $\begin{array}{l}\text { Case study on displaying } \\
\text { prices in shop windows }\end{array}$ & 0.62 & 0.64 & 0.39 & 0.34 & 0.28 & 53.847 \\
\hline $\begin{array}{l}\text { Case study on the guarantee } \\
\text { period of durable consumer } \\
\text { goods }\end{array}$ & 0.78 & 0.74 & 0.53 & 0.46 & 0.41 & 54.098 \\
\hline $\begin{array}{l}\text { Case study on the placing of a } \\
\text { product with expired 'use by' } \\
\text { date on the market }\end{array}$ & 0.91 & 0.92 & 0.81 & 0.79 & 0.69 & 27.850 \\
\hline Case study on CE marking & 0.75 & 0.79 & 0.53 & 0.57 & 0.51 & 30.889 \\
\hline $\begin{array}{l}\text { Case study on the possibility } \\
\text { to return Christmas gifts }\end{array}$ & 0.24 & 0.20 & 0.13 & 0.10 & 0.09 & 16.796 \\
\hline $\begin{array}{l}\text { Number of right answers } \\
\text { thought by the respondent - } \\
\text { tip (piece) }\end{array}$ & 10.62 & 8.36 & 7.25 & 10.64 & 5.95 & 853.095 \\
\hline $\begin{array}{l}\text { The real number of right } \\
\text { answers - fact (piece) }\end{array}$ & 6.82 & 7.11 & 4.68 & 4.32 & 3.68 & 457.998 \\
\hline Average age in segment (year) & 52.3 & 25.7 & 52.6 & 24.2 & 23.3 & 1980.571 \\
\hline Proportion of men $(\%)$ & 50.4 & 54.7 & 40.8 & 54.7 & 45.0 & 6.121 \\
\hline $\begin{array}{l}\text { Proportion of higher education } \\
\text { level (e.g. student or } \\
\text { univeristy) }(\%)\end{array}$ & 33.1 & 42.0 & 18.4 & 36.3 & 35.6 & 12.899 \\
\hline $\begin{array}{c}\text { Proportion of economic } \\
\text { studies }(\%)\end{array}$ & 33.4 & 43.1 & 21.4 & 37.3 & 31.3 & 10.641 \\
\hline Proportion of segment (\%) & 15.5 & 19.3 & 14.3 & 24.8 & 26.1 & - \\
\hline
\end{tabular}

* average value of right answers where $0=$ all answer is wrong, $1=$ all answer is right Source: own research, 2018.

The accuracy and correctness of the analysis is excellently proved by the fact that in the case of all variables I have obtained reliable values (Sig.=0,000). The F-rate values prove the correctness of the variables and the weight of the segmentation criterion. During the cluster analysis 5 established groups (segments) meant an accurate solution, and the opinion and level of knowledge of these groups can be clearly distinguished. It can be seen clearly that based on the established segments two typical categories can be separated. The most important segmentation factors are the number of right answers of course and the age of respondents.

However, in itself, the Cramer's $\mathrm{V}$ does not indicate a strong relationship between the age and the number of correct answers, the $\mathrm{V}$ value is only 0.11 , but factor and cluster analysis also justify its importance.

Without addressing the detailed characterisation of the segments, it is clear that consumer protection knowledge is low in most groups. This is especially true for members of clusters 3, 4 and 5. This is $65.2 \%$ of the total population. I would point out the cluster 4 where the average number of correct 
answers was 4.32. The number of members in the group is 534. This group provided the weakest performance. This is $24.8 \%$ of the total population. The best performing segment was segment 2 . Here the proportion of people with economic education is the highest as well as the proportion of students who attend or have graduated from tertiary education. The average number of correct answers in their case is 7.11. It is important to note that the performance of the best performing segment is also extremely poor, as it only shows a level of knowledge of $54.7 \%$. This can be hardly considered to be enough performance.

Since the size of the sample allows for the creation of a large number of segments, I have also carried out one solution for 10 and one solution for 20 clusters.

Table2: Different solution (number of clusters) of cluster-analysis

\begin{tabular}{|c|c|c|c|c|}
\hline & \multicolumn{2}{|c|}{ Cluster with the most weak result } & \multicolumn{2}{|c|}{ Cluster with the best result } \\
\cline { 2 - 5 } & $\begin{array}{c}\text { Average value } \\
\text { of correct } \\
\text { answer in } \\
\text { cluster (piece) }\end{array}$ & $\begin{array}{c}\text { Number of } \\
\text { cases in the } \\
\text { cluster (person) }\end{array}$ & $\begin{array}{c}\text { Average value } \\
\text { of correct } \\
\text { answer in } \\
\text { cluster (piece) }\end{array}$ & $\begin{array}{c}\text { Number of } \\
\text { cases in the } \\
\text { cluster (person) }\end{array}$ \\
\hline Cluster number 5 & 4.32 & 534 & 7.11 & 415 \\
\hline $\begin{array}{c}\text { Cluster number } \\
10\end{array}$ & 3.27 & 438 & 8.49 & 122 \\
\hline $\begin{array}{c}\text { Cluster number } \\
20\end{array}$ & 2.44 & 136 & 8.86 & 29 \\
\hline
\end{tabular}

Source: own research, 2018.

The test well shows the extreme values as well. The segment where the 8.86 average was achieved contained only 29 people, representing hardly $1.3 \%$ of the population.

\section{Summary}

In overall, we can say that no matter how much we love to think about ourselves as being conscious customers, this statement is generally not true. The level of consumer protection knowledge is generally insufficient in Hungary. The average number of correct answers increases with the increasing level of school education. Those middle-aged men are capable to demonstrate the highest level of knowledge, the awareness, who are graduates of tertiary economic education, but even in their case a level of awareness in terms of consumer protection is low. Only $13 \%$ of consumers have the right to say that they are knowledgeable of consumer protection at average level, while the good level was achieved only by $2.1 \%$ of the respondents. It is also evident that the school system does not prepare learners and students for practical knowledge, which is particularly discernible through the use of this test in terms of awareness on consumer protection. At the same time, few years ago, the crisis surrounding Hungarian foreign currency loans highlighted a low 
level of financial literacy. It can be stated that in the school system it may be necessary for all age groups to acquire consumer knowledge that can be used in practice. An alternative solution can be provided by quick, short-term awareness-raising and information campaigns that provide the knowledge on consumer protection. Without this, it is not worth talking about the strategy to develop consumer awareness, because consumer awareness is at extremely low level in Hungary.

\section{Acknowledgement}

This research is supported by EFOP-3.6.1-16-2016-00006 "The development and enhancement of the research potential at John von Neumann University" project. The Project is supported by the Hungarian Government and co-financed by the European Social Fund.

\section{References:}

1. GYARMATI A. (2005): Fogyasztóvédelem, Printex '96 Kft, Szolnok, p. 227

2. HENNIG-THURAU T., GWINNER K. P., WALSH G., GREMLER W. D. (2004): Electronic word-of-mouth via consumer-opinion platforms: What motivates consumers to articulate themselves on the Internet?, Journal of Interactive Marketing, volume 18, number 1, winter 2004, doi: 10.1002/dir.10073, p. 38-52

3. HOFMEISTER-TÓTH Á. - TÖRÖCSIK M. (1996): Fogyasztói magatartás, Nemzeti Tankönyvkiadó Rt., Budapest, p.13.

4. HOYER W.D., MACINNIS D.J., PIETERS R. (2013): Consumer behavior, South-Western Cengage Learning, p. 259.

5. SÜLE M. (2012): Can conscious consumption be learned? The role of Hungarian consumer protection education in becoming conscious consumers., International Journal of Consumer Studies. Mar2012, Vol. 36 Issue 2, p. 211-220

6. SUMIT R. (2013): Impulse shopping statistics, http://www.infographicsinsights.com/2011/04/impulseshopping-statistics.html, Downloaded: 1 February 2018.

7. SZÜCS R. S. (2011): A fiatalkorúak által fogyasztott néhány élelmiszeripari termék marketing és fogyasztóvédelmi szempontú vizsgálata, Debreceni Egyetem, Ihrig Károly Gazdálkodás- és Szervezéstudományok Doktori Iskola, http://hdl.handle.net/2437/103324, p. 1 - 197.

8. THE ASSOCIATION OF CONSCIENTIOUS CUSTOMERS (2017): Mit jelent a tudatos vásárlás, http://tudatosvasarlo.hu/tve/gyik, Downloaded: 1 February 2018. 